\title{
Locally Advanced Paraganglioma
}

National Cancer Institute

\section{Source}

National Cancer Institute. Locally Advanced Paraganglioma. NCI Thesaurus. Code C133713.

A parag ang lioma that has spread from its original site of growth to nearby tissues or lymph nodes. 